\title{
UPAYA MENINGKATKAN KEMAMPUAN MENGENAL WARNA MELALUI MEDIA MOZAIK UNTUK SISWA TUNAGRAHITA SEDANG KELAS III DI SDLB WIRA KUSUMA PRIGEN TAHUN AJARAN 2018/2019
}

\author{
Dwi Wahyu Rinaningsih
}

SDLB Wira Kusuma Prigen

Email: kinarayumaharani@gmail.com

\begin{abstract}
Abstrak
Penelitian ini bertujuan untuk mengetahui adanya peningkatan dengan menggunakan media mozaik terhadap kemampuan mengenal warna pada siswa tunagrahita sedang kelas III di SDLB Wira Kusuma Prigen. Penelitian ini menggunakan metode Penelitian Tindakan Kelas (PTK) model Kemmis dan Taggart. Penelitian ini dilakukan sebanyak 3 siklus. Subjek penelitian ini adalah dua orang siswa tunagrahita sedang kelas III yang berinisial AN dan NF dengan usia masing-masing 11 dan 13 tahun. Metode pengumpulan data dalam penelitian ini adalah observasi, teknik tes dan dokumentasi. Hasil penelitian tiap siklus mengalami peningkatan dari siklus I ke siklus II rata-rata 13, dari siklus I ke siklus III rata-rata 29 dan dari siklus II ke siklus III rata-rata 16. Data hasil penelitian menunjukkan adanya peningkatan kemampuan mengenal warna pada siswa tunagrahita sedang kelas III di SDLB Wira Kusuma Prigen melalui media mozaik

Kata kunci : Tunagrahita sedang, media mozaik, kemampuan mengenal warna
\end{abstract}

\section{PENDAHULUAN}

Anak-anak berkebutuhan khusus adalah anak-anak yang memiliki keunikan tersendiri dalam jenis dan karakteristiknya, yang membedakan mereka dari anak-anak pada umumnya. Salah satu anak berkebutuhan khusus yang memerlukan layanan pendidikan khusus adalah anak tunagrahita. Anak tunagrahita adalah individu yang secara signifikan memiliki intelegensi dibawah rata-rata dengan skor IQ sama atau lebih rendah dari 70 (Somantri, 2005:103).

Intelegensi yang berada dibawah rata-rata anak pada umumnya, dapat menghambat segala aktifitasnya baik dalam bersosialisasi, komunikasi dan yang lebih menonjol adalah ketidakmampuannya dalam menerima pelajaran yang bersifat akademik sebagaimana anak-anak sebayanya. Setiap anak tunagrahita adalah pribadi yang unik, karena mereka mempunyai karakteristik dan kemampuan yang berbeda-beda sesuai tingkat intelegensinya. Hambatan yang dialami dalam mengikuti pelajaran disebabkan oleh tingkat intelegensi dan berfikir abstrak yang rendah. Salah satu kesulitan siswa tunagrahita dalam pembelajaran adalah seperti mengenal warna-warna.

Pembelajaran tentang warnawarna perlu diajarkan sejak dini, sehingga ketika guru memberikan 
materi pembelajaran yang berhubungan dengan warna, tidak ada yang mengalami kesulitan, baik kesulitan untuk memahami materi yang diajarkan maupun kesulitan yang ditemui oleh guru ketika memberikan penjelasan agar mudah diterima oleh siswa. Pemberian materi diusahakan secara maksimal sesuai dengan kondisi dan kemampuan siswa tunagrahita sedang. Selain itu, juga perlu dilakukan pertimbangan dengan memperhatikan karakteristik siswa tunagrahita yang bertujuan untuk pencapaian tujuan pembelajaran serta mengembangkan kemampuan pengenalan warna pada siswa tunagrahita sedang.

Dari hasil pengamatan di SDLB Wira Kusuma Prigen terdapat 2 siswa tunagrahita sedang kelas III SDLB yang mengalami kesulitan dalam mengenal warna karena hambatan yang mereka alami. AN hanya mengenal warna merah, hal ini karena siswa menyukai warna tersebut dan tidak tertarik dengan warna-warna lainnya. Saat AN diberi tugas untuk mewarnai oleh gurunya AN selalu mewarnainya dengan warna merah saja. AN juga cenderung mengikuti suasana hati. Jika dari rumah suasana hatinya sedang kurang bagus maka akan berdampak pada pembelajaran di sekolah. Sedangkan siswa NF tidak bisa mengenal warna, hal ini terlihat saat siswa diberi pertanyaan oleh gurunya, siswa hanya asal menjawab saat diberi warna. Hal ini disebabkan karena siswa tidak fokus dan mudah terpengaruh oleh lingkungan disekitarnya.

Dari kedua kondisi siswa yang berbeda itu, berbagai metode pembelajaran mengenal warna telah dilakukan tetapi hasilnya masihbelum optimal, sehingga proses belajar tidak berjalan dengan baik dan tujuan pembelajaran tidak tercapai. Metode yang diberikan guru adalah metode ceramah, sehingga anak mengalami kesulitan dan tidak merespon. Bahkan terkadang guru hanya memberikan materi pelajaran tentang warna hanya dengan mewarnai gambar yang diberikan sehingga siswa tunagrahita sedang merasa jenuh karena materi yang diberikan membosankan.

Permasalahan diatas perlu dicari sumber permasalahannya, sehingga siswa dapat mengembangkan kemampuan mengenal warna dengan proses pembelajaran yang menyenangkan, meningkatkan motivasi untuk belajar, mengembangkan kreatifitas, mendorong imajinasi dan memperkuat daya ingat. Media mozaik ini diberikan khususnya dalam mengajarkan pengembangan kemampuan mengenal warna.

Menurut Sunaryo (dalam Muharrar dan Verayanti, 2012:48), mozaik adalah gambar atau hiasan atau pola tertentu yang dibuat dengan cara menempelkan bahan atau unsure sejenis yang disusun secara berdempetan pada sebuah bidang. Hal ini merupakan salah satu usaha untuk 
meningkatkan konsentrasi dan menarik daya minat belajar anak agar tidak mengalami kejenuhan serta meningkatkan pemahaman tentang warna melalui media mozaik pada anak tunagrahita sedang kelas III di SDLB Wira Kusuma Prigen tahun ajaran 2018/2019.

Dari latar belakang masalah di atas, selanjutnya dijabarkan satu rumusan masalah, yakni adakah Peningkatan Kemampuan Mengenal Warna Melalui Media Mozaik Untuk Siswa Tunagrahita Sedang Kelas III Di SDLB Wira Kusuma Prigen Tahun Ajaran 2018/2019.

\section{METODE}

Jenis penelitian yang digunakan adalah Penelitian Tindakan Kelas (PTK). Secara sederhana PTK dapat diartikan sebagai penelitian tindakan (action research) yang dilakukan dengan tujuan untuk memperbaiki kualitas proses dan hasil belajar sekelompok peserta didik. Dalam hal ini pengertian tindakan kelas tidak terbatas pada empat dinding kelas atau ruang kelas, tetapi lebih pada daya aktivitas belajar dua orang atau lebih peserta didik. Arikunto dkk (2006:2) menjelaskan PTK dengan memisahkan kata-kata yang tergabung di dalamnya, yakni penelitian, tindakan, dan kelas.

Pendekatan yang digunakan dalam PTK adalah pendekatan kualitatif. Pendekatan kualitatif adalah suatu pendekatan yang memaparkan suatu proses yang terjadi didalam suatu pembelajaran, baik yang terkait dengan kondisi awal pembelajaran maupun yang terjadi setelah diterapkannya suatu

Subjek penelitian dalam penelitian ini adalah seluruh responden yang ada dalam penelitian ini. Subjek penelitian ini adalah siswa SDLB Wira Kusuma Prigen kelas III dengan jumlah 2 orang siswa yang masing-masing siswa perempuan penyandang tunagrahita sedang yang berinisial AN dan NF berada antara usia 11 dan 13 tahun.

Data yang digunakan dalam penelitian ini adalah berupa observasi, tes, dan dokumentasi. Sedangkan sumber data dalam penelitian ini adalah siswa tunagrahita sedang kelas III berinisial AN dan NF yang berada di usia antara 11 dan 13 tahun beserta guru di SDLB Wira Kusuma.

Model penelitian tindakan kelas berupa rangkaian siklus yang terdiri dari empat tahapan penelitian yaitu perencanaan, tindakan, observasi dan refleksi. Model penelitian yang digunakan dalam penelitian ini adalah model penelitian Kemmis dan Mc Taggart (1968). Menurut Kemmis dan Mc. Taggart pelaksanaan penelitian tindakan mencakup empat langkah, yaitu :

a. Merumuskan masalah dan merencanakan tindakan,

b. Melaksanakan tindakan dan monitoring (pengamatan),

c. Refleksi hasil pengamatan, 


\section{d. Perencanaan untuk pengembangan selanjutnya.}

Pengumpulan data adalah cara yang dipakai dalam mengumpulkan data seperti observasi, tes, dan dokumentasi. Analisis data diperoleh setelah data-data dalam penelitian terkumpul dan digunakan untuk mendapatkan satu kesimpulan. Dalam PTK, analisis data yang digunakan adalah refleksi berdasarkan siklussiklus dalam PTK. Teknik analisis data yang digunakan adalah deskripsi kuantitatif. Data kualitatif diperoleh dari lembar observasi terhadap aktifitas siswa sedangkan data kuantitatif diperoleh dari hasil tes tulis dan tes lisan yang diberikan pada siswa.

Analisis kuantitatif digunakan untuk menganalisis data dari instrumen tes dengan cara menghitung skor yang diperoleh siswa (Arikunto, 2015:272).

\section{HASIL DAN PEMBAHASAN}

Berdasarkan hasil pengumpulan data dari seperti observasi, tes, dan dokumentasi dapat dikemukakan beberapa hasil penelitian.

Penelitian ini dilaksanakan pada tanggal 15 Agustus 2018 sampai dengan 6 September 2018. Pada penelitian ini dilakukan 4 tahap yaitu tahap prasiklus, siklus I, siklus II dan siklus III.

Kegiatan prasiklus diberikan untuk mengetahui kemampuan awal siswa tunagrahita sedang kelas III di SDLB Wira Kusuma Prigen dalam mengenal warna dasar yaitu merah, kuning, dan biru. Setelah dilakukan observasi kemudian di lanjutkan dengan refleksi dan diketahui bahwa kemampuan mengenal warna dasar pada siswa tunagrahita sedang kelas III SDLB.

Tabel 1. Penilaian hasil observasi saat dilakukan kegiatan prasiklus

\begin{tabular}{|l|l|c|}
\hline No. & $\begin{array}{l}\text { Nama } \\
\text { Siswa }\end{array}$ & Nilai \\
\hline 1. & AN & 67 \\
\hline 2. & NF & 33 \\
\hline
\end{tabular}

Tabel 2. Hasil Tes Kemampuan Mengenal Warna Pada Siklus I

\begin{tabular}{|l|l|c|}
\hline No. & $\begin{array}{c}\text { Nama } \\
\text { Siswa }\end{array}$ & Nilai \\
\hline 1. & AN & 67 \\
\hline 2. & NF & 58 \\
\hline
\end{tabular}

Tabel 3. Hasil Tes Kemampuan Mengenal Warna Pada Siklus II

\begin{tabular}{|l|l|c|}
\hline No. & $\begin{array}{c}\text { Nama } \\
\text { Siswa }\end{array}$ & Nilai \\
\hline 1. & AN & 83 \\
\hline 2. & NF & 67 \\
\hline
\end{tabular}

Tabel 4.Hasil Tes Kemampuan Mengenal Warna Pada Siklus III

\begin{tabular}{|l|l|c|}
\hline No. & \multicolumn{1}{|c|}{$\begin{array}{c}\text { Nama } \\
\text { Siswa }\end{array}$} & Nilai \\
\hline 1. & AN & 91 \\
\hline 2. & NF & 91 \\
\hline
\end{tabular}


Tabel 5. Hasil Rekapitulasi Kemampuan Mengenal Warna Siswa Tunagrahita Sedang Pada Prasiklus dan Siklus I

\begin{tabular}{|c|c|c|c|c|}
\hline \multirow[b]{2}{*}{$\begin{array}{l}\mathbf{N} \\
\text { o. }\end{array}$} & \multirow[b]{2}{*}{$\begin{array}{l}\text { Nama } \\
\text { Siswa }\end{array}$} & \multicolumn{2}{|c|}{ Tindakan } & \multirow{2}{*}{$\begin{array}{c}\text { Peningka } \\
\text { tan }\end{array}$} \\
\hline & & Prasiklus & $\begin{array}{c}\text { Siklus } \\
\text { I }\end{array}$ & \\
\hline 1. & AN & 67 & 67 & 0 \\
\hline 2. & $\mathrm{NF}$ & 33 & 58 & +25 \\
\hline
\end{tabular}

Tabel 6. Hasil Rekapitulasi Kemampuan Mengenal Warna Siswa Tunagrahita Sedang Pada Siklus I dan Siklus II

\begin{tabular}{|l|l|c|c|c|}
\hline \multirow{2}{*}{ No. } & \multirow{2}{*}{$\begin{array}{c}\text { Nama } \\
\text { Siswa }\end{array}$} & \multicolumn{2}{|c|}{ Tindakan } & Peningka \\
tan & Siklus & Siklus & \\
I & & II & \\
\hline 1. & AN & 67 & 83 & +16 \\
\hline 2. & NF & 58 & 67 & +9 \\
\hline
\end{tabular}

Tabel 7. Hasil Rekapitulasi Kemampuan Mengenal Warna Siswa Tunagrahita Sedang Pada Siklus II dan Siklus III

\begin{tabular}{|l|l|c|c|c|}
\hline \multirow{2}{*}{ No } & \multirow{2}{*}{$\begin{array}{l}\text { Nama } \\
\text { Siswa }\end{array}$} & \multicolumn{2}{|c|}{ Tindakan } & Peningka \\
\cline { 3 - 4 } & II & $\begin{array}{c}\text { Siklus } \\
\text { III }\end{array}$ & \\
\hline 1. & AN & 83 & 91 & +8 \\
\hline 2. & NF & 67 & 91 & +24 \\
\hline
\end{tabular}

Penggunaan media mozaik untuk pembelajaran mengenal warna pada siswa tunagrahita sedang kelas III di SDLB Wira Kusuma Prigen mampu menciptakan suasana pembelajaran yang menyenangkan sehingga siswa tertarik dan tidak mudah bosan. Karena pembelajaran ini di selingi dengan bermain yaitu menyatukan potonganpotongan mozaik menjadi sebuah gambar. Media mozaik ini bisa diterapkan untuk meningkatkan kemampuan mengenal warna pada siswa tunagrahita sedang. Penelitian tindakan dilaksanakan sebanyak III siklus. Tiap siklus terdiri atas 2 kali pertemuan yang masing-masing pertemuan berlangsung selama 1 jam pembelajaran.

\section{PENUTUP}

\section{Simpulan}

Berdasarkan hasil perolehan data dalam bentuk analisis deskriptif menyimpulkan bahwa siswa tunagrahita sedang kelas III di SDLB Wira Kusuma Prigen mengalami peningkatan kemampuan mengenal warna melalui media mozaik.

Pada siswa AN awalnya hanya mampu menyebutkan dan menunjukkan warna merah saja. Pada kegiatan prasiklus hasil nilai yang diperoleh AN adalah 67 dan pada NF adalah 33. Pada pelaksanaan siklus I AN mendapat nilai 67 dan NF mendapat nilai 58. Nilai yang diperoleh AN pada siklus I tetap dikarenakan mood siswa yang kurang bagus, sedangkan NF pada siklus I sudah bisa menyebutkan warna kuning. Tetapi hasil masih kurang memuaskan karena masih belum mencapai KKM.

Pada pelaksanaan siklus II AN mendapat nilai 83, AN mendapat nilai yang bagus dikarenakan mood yang 
bagus sehingga siswa sangat antusias saat mengikuti kegiatan pembelajaran. Pada NF juga mengalami penimgkatan dengan memperoleh 67 nilai karena NF sudah mulai bisa menyebutkan dan menunjukkan warna kuning dengan benar dan tanpa di bantu. Karena perolehan salah satu siswa yang masih belum mencapai KKM, maka perlu dilaksanakan siklus III dan perlu dicari kendalanya. Dan akhirnya diketahui bahwa NF mudah terpecah konsentrasinya dikarenakan suasana kelas yang kurang kondusif.

Pada siklus III hasil perolehan nilai sangat memuaskan. Nilai yang diperoleh AN dan NF adalah 91 karena siswa telah mampu menyebutkan dan menunjukkan warna dasar dengan benar. AN sudah mampu menyebutkan warna merah dan kuning serta mampu menunjukkan warna merah, kuning, dan biru. Pada NF sudah mampu menyebutkan warna biru dan kuning serta mampu saat menunjukkan warna merah, biru dan kuning.

Rata-rata penilaian tiap siklus diperoleh hasil dari siklus I ke siklus II rata-rata 13 , dari siklus I ke siklus III rata-rata 29 dan dari siklus II ke siklus III rata-rata 16.

\section{Saran}

Dari hasil simpulan diatas, berikut :

$\begin{array}{lrr}\text { Sekolah } & \text { diharapkan } & \text { dapat } \\ \text { menyediakan } & \text { berbagai } & \text { media }\end{array}$

pembelajaran yang berhubungan dengan pengembangan kemampuan kognitif untuk meningkatkan kemampuan siswa pada mata pelajaran Seni Budaya Dan Prakarya. Bagi guru hendaknya lebih meningkatkan kreatifitas dalam mencari metode dan media serta variasi pembelajaran lainnya agar dapat meningkatkan ketertarikan dan kemampuan siswa tunagrahita sedang dan untuk orang tua hendaknya menindaklanjuti kegiatan siswa di sekolah dengan melibatkan anak dalam kegiatan sehari-harinya, sehingga anak dapat mandiri sesuai dengan kondisi dan kemampuan yang dimiliki oleh anak

\section{DAFTAR PUSTAKA}

Arikunto, S, Suhardjono, dan Supardi. 2014. Penelitian Tindakan Kelas. Jakarta: BumiAksara

Arikunto, Suharsimi. 2013. DasarDasar Evaluasi Pendidikan. Jakarta:BumiAksara

Arsyad, Azhar. 2009. Media Pembelajaran. Jakarta: PT RajaGrafindo Persada

Muharrar, Syakir dan Verayanti, Sri. 2012. Kreasi Kolase, Montase, Mozaik Sederhana. Semarang: Esensi

Somantri, Sutjihati T. 2005. Psikologi Anak Luar Biasa. Bandung: Refika Aditama. 